\title{
Microbes as food for sediment-ingesting detritivores: low-density particles confer a nutritional advantage
}

\author{
J. C. Smoot ${ }^{1,2}$, R. H. Findlay ${ }^{1,3, *}$ \\ ${ }^{1}$ Department of Microbiology, Miami University, Oxford, Ohio 45056, USA \\ ${ }^{2}$ Present address: C/e ${ }^{-}$Solutions, 925 San Tomas St., Davis, California 95618, USA \\ ${ }^{3}$ Present address: Department of Biological Sciences, A-229 Bevil Building, PO Box 870206, \\ University of Alabama, Tuscaloosa, Alabama 35487, USA
}

\begin{abstract}
Detritivorous fish often selectively feed on organic-rich sediment particles, yet there is a paucity of data on the nutritional quality of different sediment fractions. A saturated cesium chloride solution was used to separate sediment from a freshwater reservoir into low- and high-density sediment fractions to mimic selective feeding on an organic-rich sediment fraction. Microbial biomass and community structure of sediment fractions were determined by phospholipid analysis. Carbon and nitrogen content and isotopic signatures were determined by elemental analysis gas source mass spectrometry. The low-density sediment fraction was enriched in organic carbon and ${ }^{12} \mathrm{C}$, had higher microbial biomass and relative abundance of microeukaryotes, and contributed less microbial carbon to total carbon when compared to the high-density sediment fraction. Stable isotope values were unable to resolve the source of organic matter present in the sediment density fractions but were able to provide a foundation to test models of gizzard shad nutrition in Acton Lake, Ohio, USA. Combined, biomimicry of selective feeding and microbiological and isotopic assessment of density-partitioned sediment indicate that deposit-feeding fishes gain a nutritionally superior food source by selectively feeding on low-density particles in freshwater habitats.
\end{abstract}

KEY WORDS: Low density sediment $\cdot$ Microbial community structure $\cdot$ Stable isotopes $\cdot$ Phospholipid fatty acid analysis

\section{INTRODUCTION}

Moore et al. (2004, p. 596) asked, 'what is actually consumed and assimilated when detritivores eat detritus...?' Their emphasis was upon the extent to which dead organic matter versus microbes are the food source. Recent findings indicate that several fishes (e.g. gizzard shad Dorosoma cepedianum, goldfish Crassius arratus, carp Cyprinus carpio, ngege tilapia Oreochromis esculentus) that feed at the sedimentwater interface possess the ability to separate lowdensity organic particles from high-density inorganic particles using crossflow filtration and concentration of food toward the esophagus via fluid motion parallel to the gill rakers (Sanderson et al. 2001, Callan \& Sanderson 2003). These findings provide an opportunity to investigate this question. Low-density organic particles in freshwater sediments may originate as bacteria, benthic algae, freshly settled phytodetritus, and allochthonous terrestrial detritus. Bacteria, benthic algae, and freshly settled phytodetritus are all potential food sources for deposit-feeding fishes, while allochthonous terrestrial detritus is thought to be refractory and thus nutritionally unavailable to these fishes. However, microbial decomposers present on and in the terrestrial detritus are also a suitable food resource. 
Measurements of gut contents and stable isotope data indicate that sediment detritus is the main carbon source for gizzard shad, although $\delta^{15} \mathrm{~N}$ values indicate that whole sediment is not the primary nitrogen source (Schaus et al. 2002, Higgins et al. 2006). Moreover, gizzard shad obtain suitable quantities of bacteria and algae from sediment to meet their required daily caloric needs (Smoot \& Findlay 2010). These findings suggest that an isotopic and microbiological assessment of density partitioned freshwater sediments will aid in the understanding of the biophysics, ecology, and evolution of benthic feeding fishes and contribute to the understanding of the role of detritus in ecosystems.

The objective of the present study was to assess the microorganisms present in high- and low-density sediment available to feeding gizzard shad. We used a combination of gas source stable isotope mass spectrometry and phospholipid fatty acid analysis of freshwater sediments from Acton Lake in southwestern Ohio, USA. Acton Lake is a well-studied reservoir with temporally and spatially distinct sediment microbial communities and a gizzard shad population that greatly impacts the reservoir's food web dynamics (Smoot \& Findlay 2001, Schaus et al. 2002).

\section{MATERIALS AND METHODS}

Sediment samples were collected December 1997 and August 1998 from Acton Lake (described in Schaus et al. 1997). The 1997 samples were collected from river, middle, and dam stations (marked by permanent buoys and corresponding to those used in Smoot \& Findlay 2001) to provide a comparison to wellcharacterized whole sediments that were known to have major physical differences and unique microbial community structures. The 1998 samples were collected concurrent with gizzard shad sampling (for gut analysis; Smoot \& Findlay 2010), approximately $40 \mathrm{~m}$ north of the river station and denoted as river' station. The depths of water column at the 4 sampling stations were approximately $9 \mathrm{~m}$ (dam station), $3 \mathrm{~m}$ (middle station), and $1 \mathrm{~m}$ (river and river' stations). Samples were analyzed for total microbial biomass, community structure, and percentage low- and high-density sediments. In addition, low- and high-density sediment fractions from December 1997 river station samples were analyzed for total organic carbon (TOC), total organic nitrogen (TON), and stable carbon and nitrogen isotope ratios $\left(\delta^{13} \mathrm{C}\right.$ and $\left.\delta^{15} \mathrm{~N}\right)$ to take advantage of concurrent sediment and water column stable isotope sampling performed by Schaus (1998).

In December 1997, 4 replicate sediment samples were collected at the river, middle, and dam stations with a KB gravity corer (Wildco) fitted with a $5 \mathrm{~cm}$ diameter plastic liner. Samples were extruded without disturbing the sediment-water interface, and the surface $1 \mathrm{~cm}$ of sediment was collected and homogenized. Subsamples $\left(1.1 \mathrm{~cm}^{3}\right.$ each) were taken with the barrel of a $5 \mathrm{ml}$ syringe (cannula end removed). One subsample from each core was lipid extracted, and 4 subsamples from each core were pooled in Oak Ridge centrifuge tubes. They were centrifuged at $9000 \times g$ for $15 \mathrm{~min}$, pore water was removed and the sediment stored for ca. 4 mo in $8 \mathrm{ml}$ of filtered, saturated cesium chloride. Approximately $15 \mathrm{~g}$ homogenized sediment from each replicate December 1997 river station core was processed for TOC, TON, $\delta^{13} \mathrm{C}$, and $\delta^{15} \mathrm{~N}$ analysis. Pore water was removed as before, and the samples were stored for ca. 4 mo in $16 \mathrm{ml}$ of filtered, saturated cesium chloride solution. In August 1998, 4 replicate cores were collected from the river' station following the procedures outlined above, except cores were collected by hand with $6.5 \mathrm{~cm}$ (inner diameter) corers, and the 4 subsamples per sample were collected directly from undisturbed surface sediment with the barrels of $5 \mathrm{ml}$ syringes $\left(1.1 \mathrm{~cm}^{3}\right.$ of sediment per subsample).

Sediment samples $\left(1.1 . \mathrm{cm}^{3}\right)$ were partitioned into lowand high-density sediment fractions in a saturated cesium chloride solution $(\rho=1.94)$ based on the work by Mayer et al. (1993), with the rationale that particles primarily composed of organic material will float in the solution and particles primarily composed of inorganic minerals will sink. Samples in saturated cesium chloride were mixed for $30 \mathrm{~min}$ at $300 \mathrm{rpm}$ at room temperature on a platform shaker and centrifuged at $35000 \times g$ for $1 \mathrm{~h}$ at room temperature in a fixed-angle rotor. Material floating on or suspended in the cesium chloride was defined as low-density sediment, and the pellet was defined as high-density sediment. Low-density sediments were weighed prior to extraction of total lipid, whereas high-density sediments were extracted for total lipid and then weighed. Low-density sediment fractions were collected from the cesium chloride solution on tared $0.2 \mathrm{~mm}$ filters (1997 samples were collected with Teflon filters, Alltech; 1998 samples with Durapore filters, Millipore) that had been cleaned of background contamination (Teflon, triplicate hot chloroform extractions; Durapore, $45 \mathrm{ml}$ deionized water rinse). Filters containing the low-density sediment were dried for $1 \mathrm{~h}$ at $100^{\circ} \mathrm{C}$, cooled under desiccation, weighed, and extracted for total lipid. High-density sediment samples were transferred to $50 \mathrm{ml}$ glass test tubes and lipid extracted. After extraction, high-density sediments were collected on weighed $2 \mathrm{~V}$ filters (Whatman), dried at $100^{\circ} \mathrm{C}$, cooled under desiccation, and weighed. Sample weights were corrected for the contribution of weight from cesium chloride by placing the weighed samples in $1 \mathrm{ml}$ of distilled water, measuring conductivity of the water, and determining the contribution of salt to dry weight. 
Sediment samples for TOC, TON, and stable isotope analyses were separated into high- and low-density sediments as above. Cesium chloride was washed from these samples with deionized water, and the samples were dried at 70 to $80^{\circ} \mathrm{C}$. Low-density sediments and $400 \mathrm{mg}$ subsamples of high-density sediments were ground, treated with $2 \mathrm{ml} 2 \mathrm{~N} \mathrm{HCl}$, dried at 70 to $80^{\circ} \mathrm{C}$, and ground again. This procedure was repeated until gas production stopped. Residual acid was neutralized with $1 \mathrm{ml} 0.4 \mathrm{M}$ dibasic phosphate buffer, and samples were dried and ground. Duplicate samples from each replicate were analyzed with a continuous flow isotope ratio mass spectrometer (medium resolution) combined with an automated sample combustion/gas separation unit using a Tracermass/Roboprep-CN stable isotope ratio mass spectrometer (Europa Scientific). Analysis from one replicate produced a negative weight percent for one of the duplicates and was removed from statistical analyses.

Total lipid was extracted from sediment, and microbial biomass and community structure were determined following the procedures outlined in Findlay (2004). Total microbial biomass in sediment was determined by measuring phospholipid phosphate (PLP). Duplicate subsamples of total lipid were oxidized with potassium persulfate at $100^{\circ} \mathrm{C}$ overnight in sealed ampules to release orthophosphate from phospholipid. Orthophosphate was reacted with ammonium molybdate and malachite green, and the phosphomolybdatemalachite green complex was detected spectrophotometrically (610 nm). Phospholipids were isolated with silica gel solid phase extraction (SPE), and their fatty acids (PLFA) were converted to fatty acid methyl esters (FAMEs) with mild alkaline methanolysis. FAMEs were purified using silica gel SPE. FAMEs were identified using gas chromatography-mass spectral analysis and quantified using gas chromatography with a flame ionization detector (Findlay 2004).

ANOVA and Tukey-Kramer post hoc pair-wise comparisons $(\alpha=0.05)$ were done using MiniTab 12 software. The efficacy of determining microbial biomass on density-fractionated sediments was determined by comparing total microbial biomass from whole sediment to microbial biomass calculated from a weighed sum of the microbial biomass present in the low- and high-density sediment. The weighed sum was determined using the weight proportions of low- and highdensity sediment. Proportional data were natural log transformed before ANOVA to achieve homoscedasticity of data (Myers 1979). Principal component analysis (PCA) of natural log transformed PLFA weight percent values [ln (wt \% + 1)] was done using MiniTab 12 . Estimates of bacterial and microeukaryotic portions of total microbial biomass were made using the molar concentrations (nmol g-1 sediment dry wt) of individual
PLFAs quantified per sample. The quantity of phospholipid from microeukaryotes was determined from the molar concentration of polyenoic PLFA assuming an average fatty acid molecular weight of 298, that $50 \%$ (mol/mol) eukaryotic membrane fatty acids are polyenoic (Findlay \& Dobbs 1993) and that the ratio of fatty acids to phosphate per phospholipid molecule is $2: 1$. Phospholipid from bacteria was determined by difference. PLP was converted to cellular carbon assuming $100 \mathrm{mmol} \mathrm{PLP} \mathrm{g}^{-1}$ carbon for bacteria and $50 \mathrm{mmol}$ PLP $~^{-1}$ carbon for microeukaryotes (Dobbs \& Findlay 1993). The cellular carbon estimates for bacteria and microeukaryotes were used to determine the total microbial carbon contribution to sediment TOC, and the microbial nitrogen portion of TON was determined by converting cellular carbon to cellular nitrogen, assuming C:N ratios of $4: 1$ and $7: 1$ for bacteria and microeukaryotes, respectively (Whitman et al. 1998, Redfield 1958).

\section{RESULTS AND DISCUSSION}

Surface sediments consisted predominantly of highdensity sediments at all sampling stations; the lowdensity fraction never exceeded $1.5 \mathrm{wt} \%$. Although sediments from the dam station tended to have a greater portion of low-density material (mean $=0.98 \mathrm{wt} \%$ ) compared to the other stations (means $<0.65 \mathrm{wt} \%$ ), there were no statistically significant differences in the proportion of low-density sediment between sampling dates or among sampling stations $(F=2.67, \mathrm{p}=0.095)$. Microbial biomass of low-density sediment was nearly 10-fold higher, on a dry wt basis, than the microbial biomass of high-density sediment and whole sediment (Fig. 1). This trend was observed regardless of sampling station. Visually, low-density sediment composition varied by station, as dam station low-density sediments were amorphous and river and river' station low-density sediments contained recognizable terrestrial plant matter.

Estimates of total microbial biomass from whole sediment versus summed fractions were equal at the middle station and greater in whole sediment versus summed fractions of sediments at the river' station, whereas the opposite trend was observed for dam station sediments (Fig. 1). 2-way ANOVA with a test for interaction effect of these data revealed (1) significant differences in total biomass among stations, (2) that the 2 methods yielded similar estimates of total microbial biomass, and (3) an interaction effect between stations and how total microbial biomass was determined (Table 1). Analysis of cell means (Myers 1979) indicated that it is appropriate to consider both main effects (differences among stations or between methods) and the interaction effect. The cause of the interaction effect is unknown. 


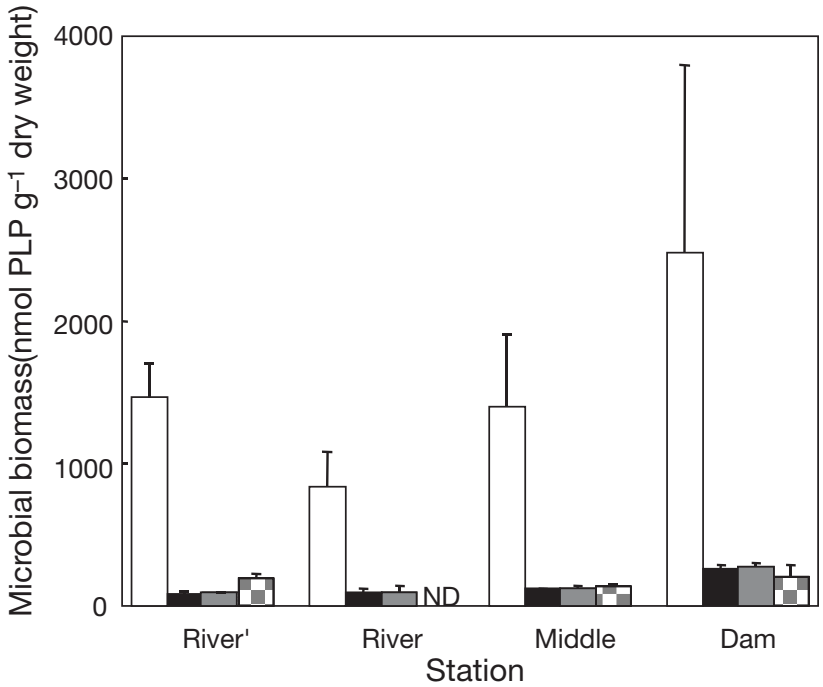

Fig. 1. Microbial biomass of whole and density-partitioned sediment from Acton Lake, Ohio, USA. Samples were collected during December 1997 at the river, middle and dam stations and during August 1998 at the river' station (where river' denotes a station ca. $40 \mathrm{~m}$ north of the river station). White bars: low-density sediment; black bars: high-density sediment; gray bars: total microbial biomass determined by adding microbial biomass of low- and high-density sediment; patterned bars: whole sediment. Bars and error bars represent means $+1 \mathrm{SD} ; \mathrm{n}=4$ except river' station whole sedimentwhere $\mathrm{n}=3$; ND $=$ not determined; PLP $=$ phospholipid phosphate

Table 1. Analysis of variance (ANOVA) comparing combined low- and high-density sediment microbial biomass with whole sediment microbial biomass from Acton Lake, Ohio, USA

\begin{tabular}{|lccccc|}
\hline Source & df & SS & MS & $F$ & $p$ \\
\hline Station & 2 & 59191 & 29596 & 23.76 & $<0.0005$ \\
Method & 1 & 1605 & 1605 & 1.29 & 0.2710 \\
Interaction & 2 & 25691 & 12846 & 10.31 & 0.0010 \\
Error & 18 & 22422 & 1246 & & \\
Total & 23 & 108909 & & & \\
\hline
\end{tabular}

PCA of PLFA profiles revealed that sediment microbial community structure varied with sediment density (Fig. 2A). All low-density sediment factor scores were negative for factor 1 , and all high-density and whole sediment factor scores were positive for factor 1. Box and whisker plots with $95 \%$ CI bands that did not overlap indicated that low-density sediment factor scores were significantly different from high-density and whole-sediment factor scores, whereas high-density and whole-sediment factor scores did not differ (Fig. 2B). Bacterial fatty acids (branched fatty acids, cyclopropyl fatty acids, and odd number carbon length fatty acids) were disproportionately more abundant in high-density and whole sediment samples. Specifically, these fatty acids were indicative of aerobic bac-

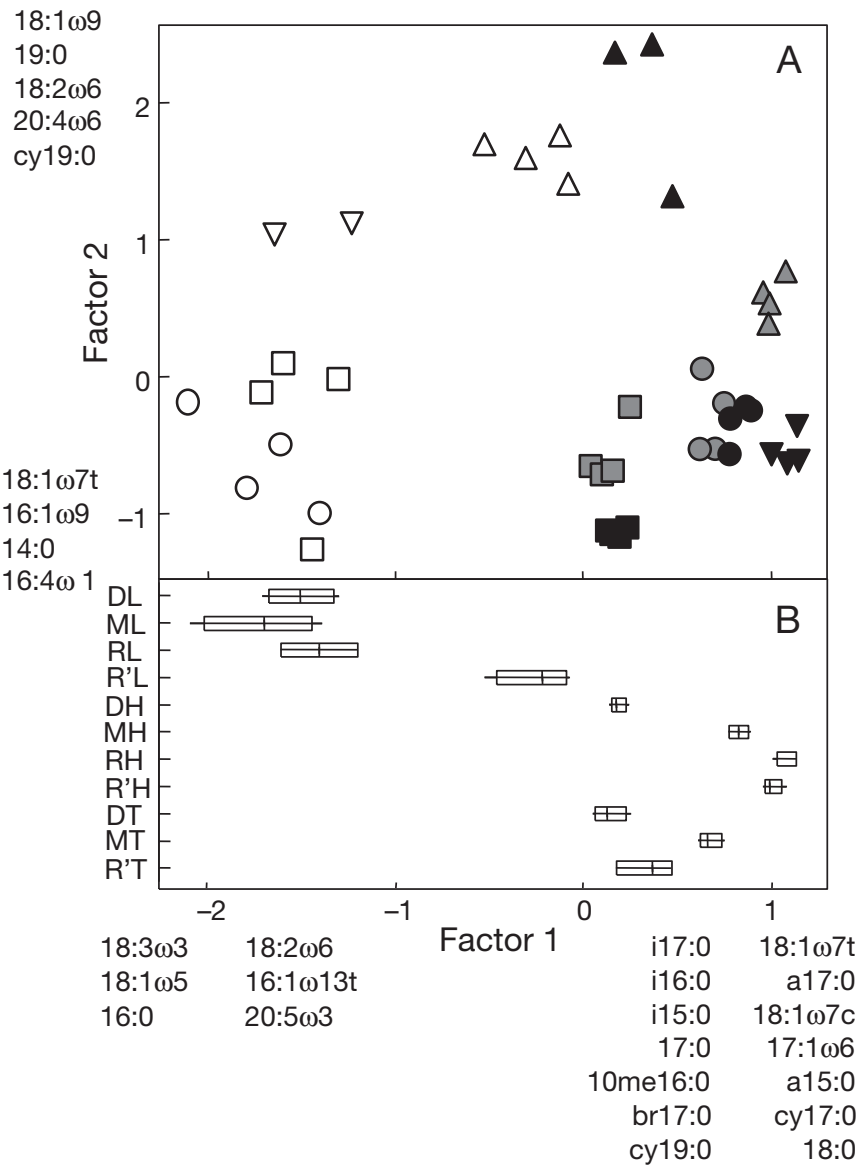

Fig. 2. Analysis of microbial community structure associated with sediment fractions. (A) Scatter plot of PCA factor 1 scores by factor 2 scores of PLFA profiles from low-density, highdensity, and total sediment collected in Acton Lake. Symbols indicate individual replicates and are coded by location $(\Delta$ : river'; $\nabla$ : river; $\mathrm{O}$ : middle; $\square$ : dam) and sediment fraction (open: low-density; black: high-density; gray: whole sediment). Influential fatty acids (factor loading $>10.5 \mid$ ) listed near the axes termini are disproportionately abundant in samples plotting near those termini. Replicates are as described in Fig. 1, except that the river station whole sediment samples were lost during PLFA analysis. (B) Box and whisker (with whiskers representing $95 \%$ confidence intervals) plot of factor 1 scores for all treatments. Samples are coded by location (R': river'; R: river; M: middle; $\mathrm{D}$ : dam) and sediment fraction (L: low-density; H: high-density; $\mathrm{T}$ : whole sediment)

teria $(18: 1 \omega 7 \mathrm{c}$ and $18: 1 \omega 7 \mathrm{t})$, anaerobic bacteria (cy17:0 and cy19:0), sulfate-reducing bacteria (10me16:0 and

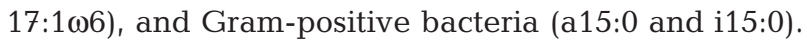
Microeukaryotic and, in particular, algal fatty acid

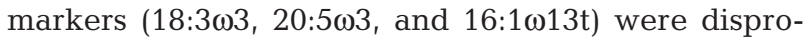
portionately more abundant in low-density sediment samples. Further, factor 2 scores were influenced by fatty acid markers for aerobic Gram-negative bacteria

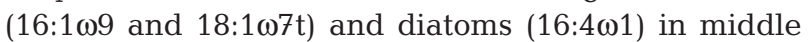
and dam station samples, and fatty acid markers for

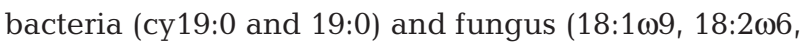




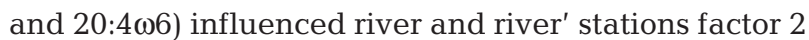
scores (Fig. 2A). Although there was an enrichment of microeukaryotes in low-density sediment, bacteria constituted the majority $(77.0 \pm 3.8[\mathrm{SD}] \%)$ of the microbial biomass in the low-density sediment regardless of sampling date or station.

The weight percent of TOC in December 1997 river station low-density sediments was 12-fold greater than in high-density sediments ( $p<0.0005$; Table 2$)$. Lowdensity sediment had a $\delta^{13} \mathrm{C}$ of $-26.64 \%$ o while highdensity sediment has a $\delta^{13} \mathrm{C}$ of $-23.08 \%$ indicating that the organic matter in the low-density fraction was enriched in ${ }^{12} \mathrm{C}$ compared to high-density sediment organic matter $(p<0.0005)$. Although the concentration of microbial biomass was greater in low-density sediments compared to high-density sediments (Fig. 1), the microbial biomass contribution to TOC was less in the low-density fraction compared to the highdensity fraction (Table 2) due to the contributions of particulate plant detritus to the low-density sediments that are not present in the high-density sediments. The C:N atomic ratio of 20.7:1 in low-density sediments is also consistent with terrestrial plant detritus comprising a substantial portion of the organic carbon of the low-density sediments (Komada \& Reimers 2001), although this ratio also indicates the presence of significant microbial biomass. Low-density sediment was enriched for TON and ${ }^{15} \mathrm{~N}$ compared to high-density sediment (Table 2), which indicates microbial colonization and reworking of amino acids (Keil \& Fogel 2001). In addition, microbial carbon to total carbon ratios for high-density sediments were approximately $2 \times$ that of low-density sediments, whereas total microbial nitrogen contributions to total nitrogen were comparable supporting the PLFA-based findings that heterotrophic bacteria dominated the microbial biomass

Table 2. High- and low- density sediment from the river station in Acton Lake, Ohio, USA. For total organic carbon (TOC) and total organic nitrogen (TON), results are means $( \pm \mathrm{SD})$ weight $\%$ per dry wt of sample, $\mathrm{n}=4$; for $\delta^{13} \mathrm{C}$ and $\delta^{13} \mathrm{~N}$, results are means $( \pm \mathrm{SD}) \%, \mathrm{n}=4$ except $\delta^{15} \mathrm{~N}$ from the highdensity fraction where $\mathrm{n}=3$; for $\mathrm{C}_{\text {MICROBIAL }}$ (portion of total carbon attributed to microbial biomass) and $\mathrm{N}_{\text {MICROBIAL (por- }}$ tion of organic nitrogen attributed to microbial biomass) results are mean $\%( \pm \mathrm{SD}), \mathrm{n}=2$

\begin{tabular}{|lrrrr|}
\hline \multirow{2}{*}{ Assay } & \multicolumn{2}{c}{ Sediment fraction } & \multicolumn{1}{l}{$F$} & p \\
& \multicolumn{1}{c}{ High } & Low & & \\
\hline TOC & $0.78(0.15)$ & $9.52(1.56)$ & 110.8 & $<0.0005$ \\
TON & $0.10(0.02)$ & $0.46(0.10)$ & 121.0 & $<0.0005$ \\
$\delta^{13} \mathrm{C}$ & $-23.08(0.46)$ & $-26.64(0.18)$ & 210.0 & $<0.0005$ \\
$\delta^{15} \mathrm{~N}$ & $5.63(0.95)$ & $8.52(1.11)$ & 13.8 & 0.0140 \\
$\mathrm{C}_{\text {MICROBIAL }}$ & $8.86(0.75)$ & $4.80(1.22)$ & 24.1 & 0.0080 \\
$\mathrm{~N}_{\text {MICROBIAL }}$ & $22.73(3.61)$ & $21.82(5.64)$ & 0.1 & 0.7900 \\
& & & & \\
\hline
\end{tabular}

of high-density sediment and that a combination of algal and bacterial biomass and terrestrial plant detritus influenced the $\mathrm{C}: \mathrm{N}$ atomic ratio in the low-density sediments.

Cesium chloride fractionation and quantitative analysis of Acton Lake sediment fractions provided a biomimic approximation of density-dependent selective feeding and revealed the significance of the evolution of crossflow filtration in deposit-feeding fishes. For instance, using these sediments and the measured selective ingestion by gizzard shad as an example (a 7 -fold increase in ingestion of low-density particles) (Smoot \& Findlay 2010), an organism selectively feeding on low-density particles, as opposed to feeding indiscriminately on whole sediment, gains a food resource that is nearly 10 -fold higher in microbial biomass and is comprised of an approximately equal mixture of microeukaryotes and bacteria. This food resource would also be enriched 12 -fold in TOC and 4.6-fold in TON compared to high-density particles. However, the living biomass is likely diluted with refractory organic carbon (as opposed to mineral matter which dilutes the digestively available organic matter associated with high density particles), as there is a nearly 2 -fold decrease in the ratio of total microbial carbon to TOC. A similar dilution does not occur for organic nitrogen, as the contribution of living biomass to TON is equal in the 2 fractions. Ultimately, the capacity to enrich ingesta in low-density particles relative to bulk sediment by crossflow filtration results in significant increases in the food quality of ingested material for deposit-feeding fishes. The similarity in food resources among gizzard shad and freshwater mussels suggest that crossflow filtration gives deposit feeders access to food similar in quality to that used by many filter feeders (Christian et al. 2004, Smoot \& Findlay 2010). These findings also support previous stable isotope studies that showed significant utilization of bacterial carbon by aquatic insects in first-order streams (Hall \& Meyer 1998), and the classic 'peanut butter and nutritionally unsuitable crackers' analogy widely used to describe the processing of leaf litter by shredder aquatic insects in streams (Cummins 1974), although in this case the microbial food resource is mainly fungi. However, in marine systems microbial biomass and particularly bacterial biomass has been viewed as insufficient to support the metabolic needs of deposit feeders (Lopez \& Levinton 1987), although bacteria have been recognized as important sources of organic nitrogen (Mayer et al. 1993). It remains to be determined if these differences arise from fundamental differences between freshwater and marine systems or are an artifact of different experimental approaches.

Gizzard shad in Acton Lake when feeding near the river' station increase their intake of low-density parti- 
cles 7 -fold compared to whole sediment, yet lowdensity particles comprise only $5 \%$ of their ingesta (Smoot \& Findlay 2010). Lipid analysis of the gut fluids indicate that gizzard shad digest both phytoplankton and bacteria in approximately equal proportions and that these microorganisms are their main food source (Smoot \& Findlay 2010). Stable isotope studies indicate that during October 1997, $80 \%$ of adult shad carbon was derived from sediment detritus and the remainder from zooplankton (Schaus et al. 2002); these calculations were made with a 2-component mixing model and stable isotope values from bulk sediment. Our December $1997 \delta^{13} \mathrm{C}$ and $\delta^{15} \mathrm{~N}$ values for low-density sediment are comparable to the values for October 1997 zooplankton $(-26.6 \%$, $8.5 \%$ vs. $-26.7 \%$, $8.4 \%$ ), suggesting an alternative source of gizzard shad carbon and nitrogen, that is gizzard shad assimilate approximately $50 \%$ of their carbon from low-density sediment and approximately $50 \%$ from high-density sediment. Stable nitrogen isotope ratios in gizzard shad tissue average $14.0 \%$ and are 8 to $10 \%$ greater than whole sediment $\delta^{15} \mathrm{~N}$ values, indicating an intervening trophic level between fish and sediments (Schaus 1998, Adams \& Sterner 2000, Schaus et al. 2002). The low-density sediment $\delta^{15} \mathrm{~N}$ was approximately halfway between whole sediment and gizzard shad tissue values, suggesting that the microbial biomass of low-density sediment contributed to the observed isotope fractionation and was an intervening trophic level between the fish and whole sediment. These data are in agreement with conventional gut analyses presented by Schaus et al. (2002), which indicate that zooplankton rarely contribute more than a few percent to gizzard shad carbon.

None of the analyses conducted in the present study allow discrimination among the potential sources of sediment organic carbon. The range of $\delta^{13} \mathrm{C}$ values for mid-latitude C3 terrestrial plants is typically given as -26 to $-30 \%$ o (McCallister et al. 2004) and suggests that carbon in Acton Lake low-density sediments originates as allochthonous detritus. Indeed, the isotope data support the qualitative observations of plant debris in the low-density fraction of the river and river' station sediments (Bender 1971). However, these values are also consistent with the low-density material being comprised of phytodetritus, as zooplankton from Acton Lake averaged $\delta^{13} \mathrm{C}$ values of approximately $26.70 \%$ during the fall of 1997 (Schaus et al 2002). Carbon fractionation by heterotrophs is generally considered to be small (see, however, Barnes et al. 2007), and the similarity between lowdensity sediment and zooplankton $\delta^{13} \mathrm{C}$ values suggests the ultimate source of carbon is microalgal biomass, present either as benthic algae or as recently settled phytodetritus (France 1995). The source of car- bon in the high-density fraction remains to be elucidated as it is outside the range typically given for C3 terrestrial plant matter (Bender 1971), dissolved organic matter originating in terrestrial soils, and Acton Lake seston reported by Schaus (1998). Application of fractionation and chemical analysis techniques being pioneered in marine systems (Dickens et al. 2006, Coppola et al. 2007) may help resolve questions as to the origin of organic carbon utilized by microorganisms within the various density fractions of freshwater sediments and further our understanding of microorganisms as a food resource for detritivors.

Acknowledgements. We thank L. Schick and L. Mayer, Darling Marine Center, University of Maine, for their technical assistance with density separation procedures. We thank the Department of Zoology, Miami University, for sampling gear and especially M. Schaus for technical assistance throughout this study. The Department of Microbiology, Miami University, supported this study. Two anonymous reviewers and the contributing editor provided helpful suggestions to previous versions of this manuscript.

\section{LITERATURE CITED}

Adams TS, Sterner RW (2000) The effect of dietary nitrogen content on trophic level ${ }^{15} \mathrm{~N}$ enrichment. Limnol Oceanogr 45:601-607

Barnes C, Sweeting CJ, Jennings S, Barry JT, Polunin NVC (2007) Effect of temperature and ration size on carbon and nitrogen stable isotope trophic fractionation. Funct Ecol 21:356-362

Bender MM (1971) Variations in the ${ }^{13} \mathrm{C} /{ }^{12} \mathrm{C}$ ratios of plants in relation to the pathway of photosynthesic carbon dioxide formation. Phytochemistry 10:1239-1244

Callan WT, Sanderson SL (2003) Feeding mechanisms in carp: crossflow filtration, palatal protrusions and flow reversals. J Exp Biol 206:883-892

Christian AD, Smith BN, Berg DJ, Smoot JC, Findlay RH (2004) Trophic position and potential food sources of two species of unionid bivalves (Mollusca: Unionidae) in two small Ohio streams. J N Am Benthol Soc 23:101-113

Coppola L, Gustafsson O, Andersson P, Eglinton TI, Uchida M, Dickens AF (2007) The importance of ultrafine particles as a control on the distribution of organic carbon in Washington Margin and Cascadia Basin sediments. Chem Geol 243:142-156

Cummins KW (1974) Structure and function of stream ecosystems. BioScience 24:631-641

Dickens AF, Baldock JA, Smernik RJ, Wakeham SG, Arnarson TS, Gelinas Y, Hedges JI (2006) Solid-state ${ }^{13} \mathrm{C}$ NMR analysis of size and density fractions of marine sediments: insight into organic carbon sources and preservation mechanisms. Geochim Cosmochim Acta 70:666-686

Dobbs FC, Findlay RH (1993) Analysis of microbial lipids to determine biomass and detect the response of sedimentary microorganism to disturbance. In: Kemp PF, Sherr BF, Sherr EB, Cole JJ (eds) Handbook of methods in aquatic microbial ecology. Lewis Publishers, Boca Raton, FL

Findlay RH (2004) Determination of microbial community structure using phospholipid fatty acid profiles. In: Kowalchuk GA, De Bruijn FJ, Head IM, Akkermans ADL, Van Elsas JD (eds) Molecular microbial ecology manual, 
2nd edn. Kluwer Academic Publishers, Dordrecht

Findlay RH, Dobbs FC (1993) Quantitative description of microbial communities using lipid analysis. In: Kemp PF, Sherr BF, Sherr EB, Cole JJ (eds) Handbook of methods in aquatic microbial ecology. Lewis Publishers, Boca Raton, FL

France RL (1995) Carbon-13 enrichment in benthic compared to plantonic algae: foodweb implications. Mar Ecol Prog Ser 124:307-312

Hall RO, Meyer JL (1998) The trophic significance of bacteria in a detritus-based stream food web. Ecology 79: 1995-2012

Higgins KA, Vanni MJ, Gonzalez MJ (2006) Detritivory and the stoichiometry of nutrient cycling by a dominant fish species in lakes of varying productivity. Oikos 114:419-430

Keil RG, Fogel ML (2001) Reworking of amino acid in marine sediments: stable carbon isotopic composition of amino acids in sediments along the Washington coast. Limnol Oceanogr 46:14-23

Komada T, Reimers CE (2001) Resuspension-induced partitioning of organic carbon between solid and solution phases from a river-ocean transition. Mar Chem 76: $155-174$

Lopez GP, Levinton JS (1987) Ecology of deposit-feeding animals in marine sediments. Q Rev Biol 62:235-260

Mayer LM, Jumars PA, Taghon GL, Macko SA, Trumbore S (1993) Low-density particles as potential nitrogenous food sources for benthos. J Mar Res 51:373-389

McCallister SL, Bauer JE, Cherrier JE, Ducklow HW (2004) Assessing sources and ages of organic matter supporting river and estuarine bacterial production: a multiple-isotope $\left(\delta^{14} \mathrm{C}, \delta^{13} \mathrm{C}\right.$, and $\left.\delta^{15} \mathrm{~N}\right)$ approach. Limnol Oceanogr

Editorial responsibility: Rutger de Wit, Montpellier, France
49:1687-1702

> Moore JC, Berlow EL, Coleman DC, de Ruiter PC and others (2004) Detritus, trophic dynamics and biodiversity. Ecol Lett 7:584-600

Myers JL (1979) Fundamentals of experimental design, 3rd edn. Allyn \& Bacon, Boston, MA

Redfield AC (1958) The biological control of chemical factors in the environment. Am Sci 46:205-221

> Sanderson SL, Cheer AY, Goodrich JS, Graziano JD, Callan WT (2001) Crossflow filtration in suspension-feeding fishes. Nature 412:439-441

Schaus MH (1998) Effect of gizzard shad on nutrient cycles and phytoplanton in a reservoir ecosystem: roles of diet, biomass, and population structure. PhD dissertation, Miami University, Oxford, $\mathrm{OH}$

Schaus MH, Vanni MJ, Wissing TE, Bremigan MT, Garvey JE, Stein RA (1997) Nitrogen and phosphorus excretion by detritivorous gizzard shad in a reservoir ecosystem. Limnol Oceanogr 42:1386-1397

Schaus MH, Vanni MJ, Wissing TE (2002) Biomass-dependent diet shifts in omnivorous gizzard shad: implications for growth, food web, and ecosystem effects. Trans Am Fish Soc 131:40-54

Smoot JC, Findlay RH (2001) Spatial and seasonal variation in a reservoir sedimentary microbial community as determined by phospholipid analysis. Microb Ecol 42:350-358

Smoot JC, Findlay RH (2010) Caloric needs of detritivorous gizzard shad Dorosoma cepedianum are met with sediment bacterial and algal biomass. Aquat Biol 8:105-114

Whitman WB, Coleman DC, Wiebe WJ (1998) Prokaryotes: the unseen majority. Proc Natl Acad Sci USA 95: 6578-6583

Submitted: April 30, 2009; Accepted: October 14, 2009 Proofs received from author(s): March 16, 2010 